\title{
THE TURNOVER OF HEMOGLOBINS A, F, AND A IN THE PERIPHERAL BLOOD OF THREE PATIENTS WITH THALASSEMIA *
}

\author{
By THOMAS G. GABUZDA, $\dagger$ DAVID G. NATHAN, $\ddagger$ AND FRANK H. GARDNER \\ WITH THE TECHNICAL ASSISTANCE OF ANNE COUNCIL AND \\ ALVERA LIMAURO \\ (From the Richard C. Curtis Hematology Research Laboratory, Peter Bent Brigham \\ Hospital, and the Department of Medicine, Harvard Medical School, \\ Boston, Mass.)
}

(Submitted for publication April 23, 1963; accepted July 11, 1963)

The presence of red-cell hypochromia in thalassemia has led to the belief that the primary reason for this disorder is defective hemoglobin synthesis. Itano (1) first enunciated and Ingram and Stretton (2) elaborated on the proposition that in "beta" thalassemia there is a suppression of the production of the beta polypeptide chains that, with the alpha chains, make up normal adult hemoglobin $\left(\alpha_{2} \beta_{2}\right)$. This would lead to a diminished concentration in the blood of hemoglobin A, and allow for compensatory or relative increases of hemoglobins $\mathrm{F}\left(\alpha_{2} \gamma_{2}\right)$ and $\mathrm{A}_{2}\left(\alpha_{2} \delta_{2}\right)$, neither containing beta chains. On the other hand, in "alpha" thalassemia it is proposed that the production of alpha chains is diminished, and since both hemoglobins $F$ and $A_{2}$, in common with $A$, contain the alpha chain, one does not find compensatory or relative increases of $\mathrm{F}$ and $\mathrm{A}_{2}$. Hemoglobin $\mathrm{H}$, the beta-chain tetramer, may be found in pedigrees of this type. The genetic evidence which has accumulated to date provides support for this theory (3).

Studies of marrow morphology and of iron and porphyrin metabolism, in contrast to the concept of suppressed production of hemoglobin, suggest a severe dyspoiesis of hemoglobin syn-

* Supported in part by the John A. Hartford Foundation, a grant from the Squibb Institute for Medical Research, and U. S. Public Health Service grants AM-00965 (C6, 7, 8). A preliminary report of this work appeared in Nature (Lond.) 1962, 196, 781.

$\dagger$ Research Fellow, supported by U. S. Public Health Service fellowship (HPD-9250-C2) from the National Heart Institute.

¥ Medical Foundation Research Fellow.

$\S$ Supported in part by U. S. Public Health Service research career program award (HE-K3-14,927) from the National Heart Institute. thesis in thalassemia. Large quantities of hemoglobin are apparently produced, but undergo premature destruction in the marrow (ineffective erythropoiesis) (4-9). Most of the hemoglobin released into the peripheral blood does not usually achieve a normal survival. Small differences in the relative turnover rates of the various circulating hemoglobins may be greatly magnified in the process of ineffective erythropoiesis.

This study deals chiefly with the cellular distribution of the hemoglobins and the relative rates at which they are synthesized and catabolized in the peripheral blood. The information derived assists in our understanding of thalassemia as a genetic defect of globin metabolism.

\section{MATERIALS AND METHODS}

The basic plan of this study was to follow the rate of appearance and disappearance of an isotopically labeled amino acid in the circulating pools of hemoglobins $A, F$, and $A_{2}$ in three patients with thalassemia.

1. Patients. All three men showed the characteristic features of thalassemia and might be placed in an "intermediate" clinical category because of their relatively benign clinical courses; the patients were ambulatory during the studies. None had required transfusion in recent years. Each was physically active, but had mild anemia. Clinical data describing the patients are summarized in Table I. Although the state of homozygosity is difficult to define in thalassemia, the large quantities of fetal hemoglobin (from 22 to 94\%) and the family studies were consistent with homozygosity in the patients (see Appendix). Patient J.C. had moderate splenomegaly, whereas the other two patients had had splenectomy a number of years previously. The increased numbers of circulating normoblasts in these two patients probably occurred as a result of removal of the spleen. Red-cell morphology was characteristic of thalassemia in all patients because there was anisocytosis, poikilocytosis, hypochromia, target cells, and schistocytes. 


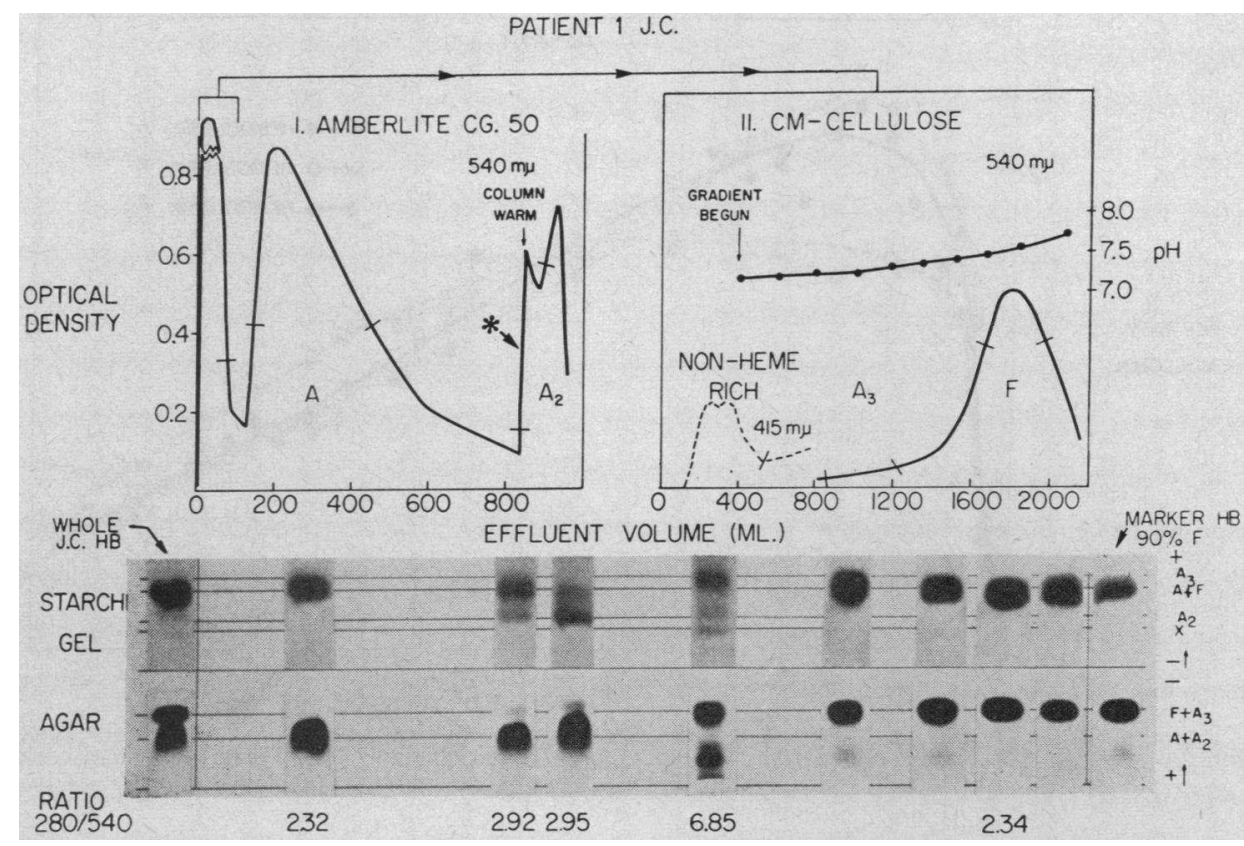

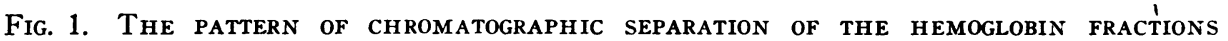
USED FOR RADIOACTIVE ANALYSIS IN PATIENTS WITH THALASSEMIA GIVEN GLYCINE-2-C'4. Description of the buffers used appears in the text. Hemoglobin $A_{2}$ was eluted by raising the column temperature to $30^{\circ} \mathrm{C}$. Hemoglobin $A_{3}$ is designated according to the terminology of Kunkel and Bearn (23).

Patient S.D. showed the most marked morphological alteration.

Each patient received an iv injection of $200 \mu \mathrm{c}$ of glycine-2- $\mathrm{C}^{14}$ (SA, $40 \mu \mathrm{c}$ per $\mathrm{mg}$ ). ${ }^{1}$ Blood samples were then taken daily for 10 days and then once or twice weekly for a total of 3 to 4 months, with heparin or acid citrate dextrose solution as the anticoagulant. Within 1 day of sample collection, the red cells were washed three times in 3 vol of saline, hemolyzed with 3 vol of water and $0.5 \mathrm{vol}$ of toluene, shaken, and allowed to stand overnight at $4^{\circ} \mathrm{C}$. The stroma was next separated in the Spinco model $L$ ultracentrifuge at $138,000 \times g$ for 1 hour. The clear hemoglobin solution was then placed in dialysis tubing and stored at $4^{\circ} \mathrm{C}$ in the phosphate-cyanide buffer used for chromatographic separation. The period between sampling and chromatographic separation did not exceed 2 weeks.

2. Hemoglobin separation. Column chromatography was carried out in two stages, as illustrated in Figure 1. After preliminary fractionation of 750 to $1,000 \mathrm{mg}$ of hemoglobin on Amberlite CG 50 with developer no. 2 of Allen, Schroeder, and Balog (10), fetal hemoglobin was further purified on carboxymethylcellulose by gradient elution according to the system of Huisman, Martis, and Dozy (11). The method of separation was modified slightly in the case of patient C.G. because of the small amounts of hemoglobins $A$ and $A_{2}$ in his blood. (The

1 New England Nuclear Corporation, Boston, Mass.
Amberlite buffer $\mathrm{pH}$ was lowered from 7.18 to 7.10 , and the phosphate molarity decreased from .044 to .042 . The column temperature was increased with a heating tape from $4^{\circ} \mathrm{C}$ to $15^{\circ} \mathrm{C}$ to elute hemoglobin $\mathrm{A}$ and to $30^{\circ}$ $\mathrm{C}$ to elute hemoglobin $\mathrm{A}_{2}$.) An automatic method of protein analysis was used to facilitate the separation of large numbers of samples: The separated dilute fractions were concentrated to small volumes by ultrafiltration through dialysis tubing. After dialysis against running tap water for 12 hours, they were lyophilized and the protein was stored in tightly stoppered vials.

3. Determination of protein purity. One chromatographic separation was reserved for electrophoretic analysis of the separated concentrated fractions on starch gel and agar. Electrophoretic homogeneity was demonstrated for the $\mathrm{A}$ and $\mathrm{F}$ fractions of patients J.C. and S.D. There was some contamination of the $A_{2}$. fractions with approximately $20 \% \mathrm{~A}$ and a trace of $\mathrm{F}$. The ratio obtained by dividing the spectrophotometric reading found at $280 \mathrm{~m} \mu$ by that at $540 \mathrm{~m} \mu$ was used to identify the fraction rich in nonheme proteins. In the case of patient C.G., all of the $A$ and $A_{2}$ fractions of the study were electrophoretically analyzed on agar and starch gel, respectively. These fractions showed only the slightest traces of hemoglobin $\mathrm{F}$ as a contaminant of the $A$ fractions. The $A_{2}$ fractions contained an average of about $25 \%$ hemoglobin A. Samples of less than 3.5 mg were discarded.

4. Addition of carrier hemoglobin. The hemoglobins 


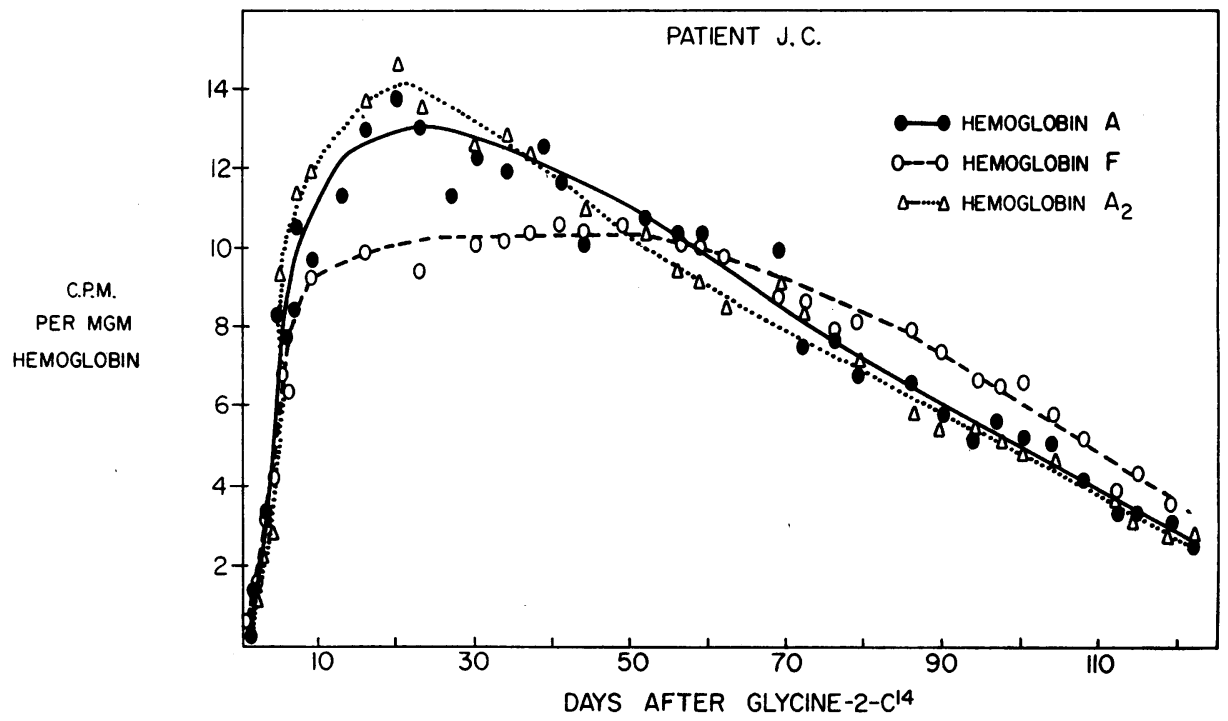

Fig. 2. SA of $C^{14}$ IN The individual hemoglobins of Patient J.C. DURing 122 days After INJECTION OF GLYCINE-2-C ${ }^{14}$.

$A$ and $A_{2}$ of patient C.G. were present in such small amounts that before dialysis and lyophilization, measured amounts of carrier hemoglobin were added to measured amounts of the samples. The hemoglobin concentrations were measured in the Beckman DU spectrophotometer as cyanmethemoglobin at $540 \mathrm{~m} \mu$ or $420 \mathrm{~m} \mu$. SA was then multiplied by the appropriate correction factor.

5. Radioactivity analysis. Weighed amounts of the lyophilized samples were completely burned in oxygencontaining flasks, and the trapped $\mathrm{C}^{14} \mathrm{O}_{2}$ was counted in a liquid scintillation counter $(12,13)$. The counting error (ratio of $2 \mathrm{SD}$ of the count rate to the net count rate) was no greater than $3 \%$.

6. Preparation of reticulocyte-rich and -poor cells. The preparation of reticulocyte-rich and -poor cell populations was accomplished by cold ultracentrifugation of $15 \mathrm{ml}$ of blood in celluloid tubes at $11,000 \times g$ for 1 hour. The top millimeter of cells was used as the reticulocyte-rich preparation, whereas the bottom $3 \mathrm{~mm}$ was taken as the reticulocyte-poor layer. The celluloid tubes were sliced with a mechanical tube slicer to obtain the

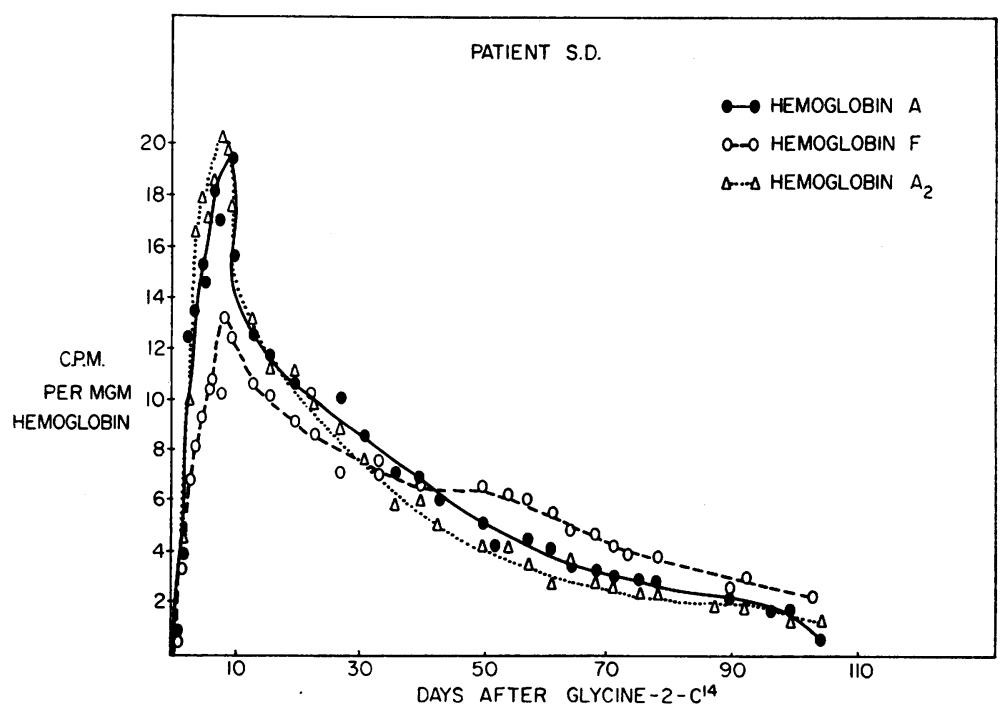

Fig. 3. SA of $\mathrm{C}^{14}$ in the individual hemoglobins of patient S.D. DURING 100 DAYS AFTER INJECTION OF GLYCINE-2-C ${ }^{14}$. 


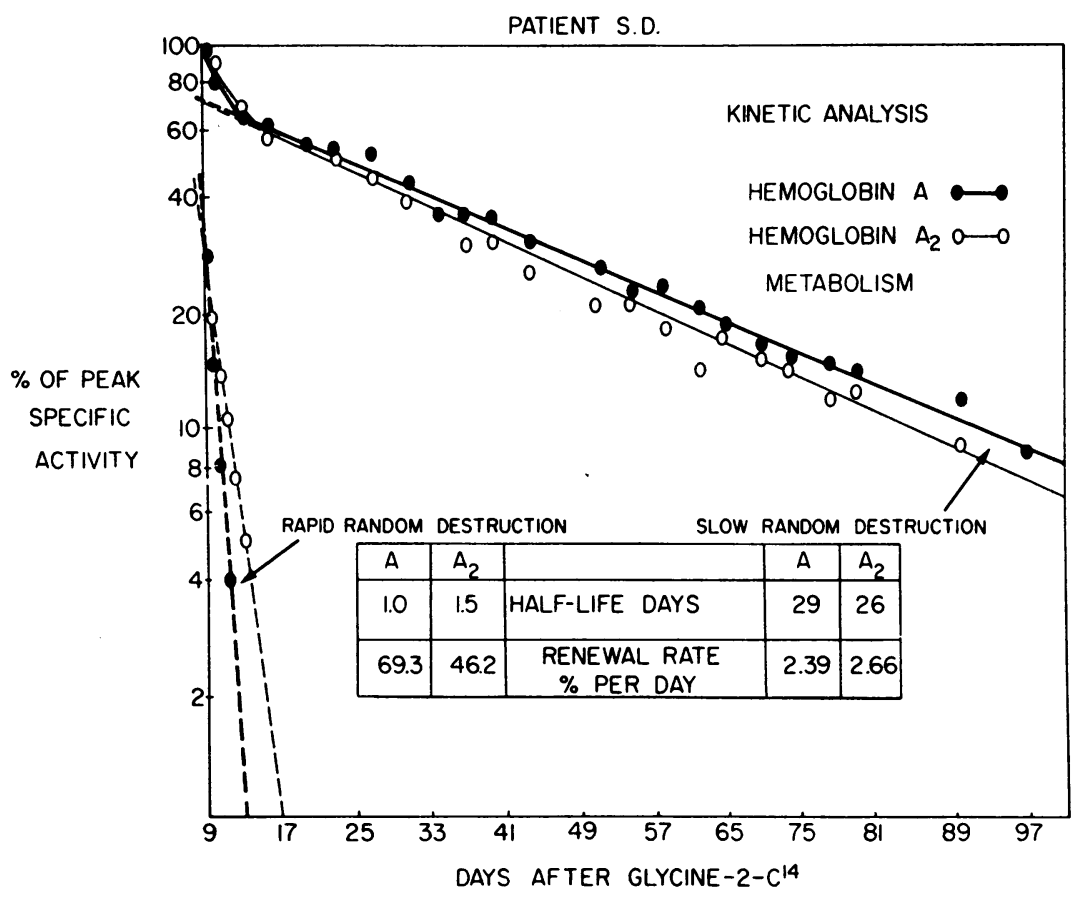

Fig. 4. Plot on semilogarithmic scale of SA of hemoglobins A and $\mathrm{A}_{2}$ FROM PEAK ACTIVITY ONWARD FOR PATIENT S.D. The curve is analyzed as the summation of two straight-line functions.

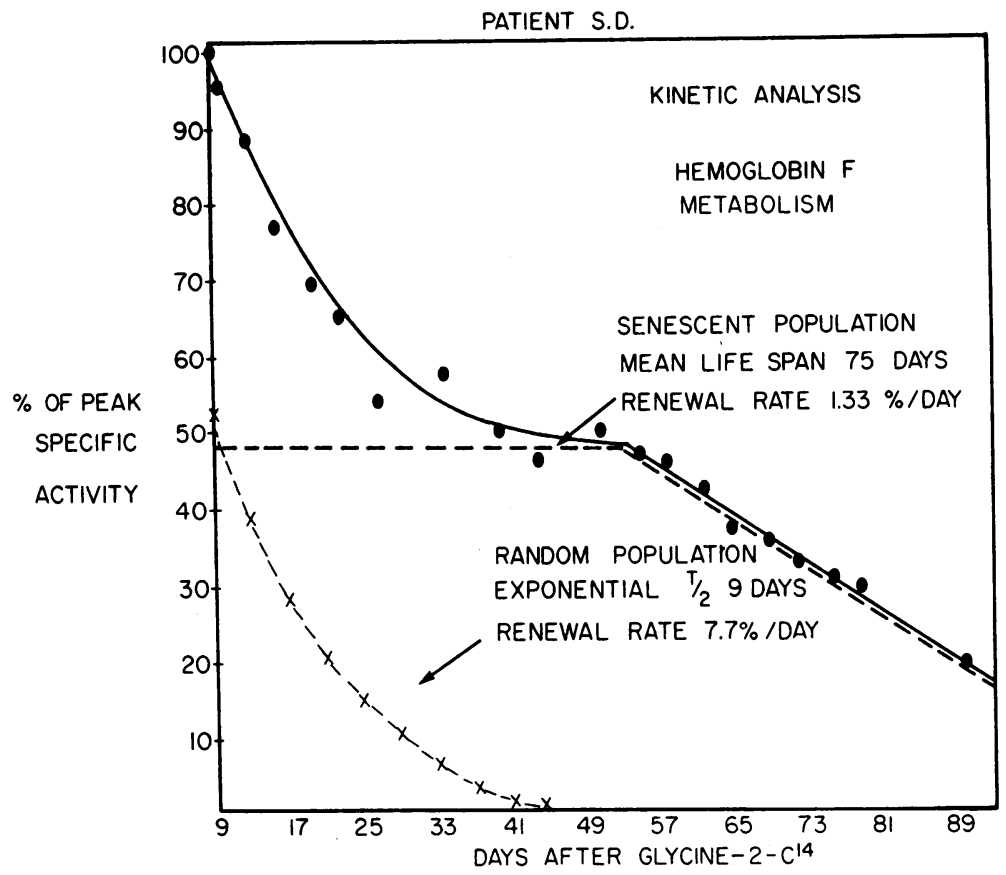

Fig. 5. Plot on linear scale of SA of hemoglobin F from the peak ONWARD FOR PATIENT S.D. The curve is analyzed, as shown by the dotted lines, into the summation of two curves, an exponential function sitting on a curve of "senescence." 


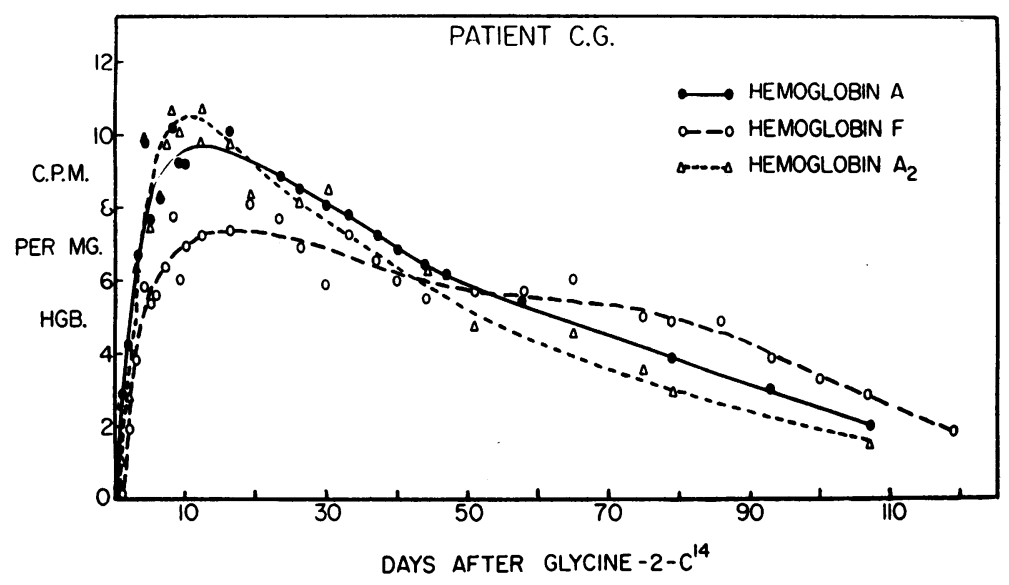

Fig. 6. SA OF $\mathrm{C}^{14}$ IN THE INDIVIDUAL HEMOglobins OF PATIENT C.G. DURING 120 DAYS AFTER INJECTION OF GLYCINE-2-C ${ }^{14}$.

layers. In most cases, preliminary reticulocyte enrichment was accomplished by a series of 3 centrifugations of $120 \mathrm{ml}$ of blood at $2,000 \mathrm{rpm}$ in the cold before a final centrifugation of the reticulocyte-enriched mixture in the ultracentrifuge. In addition to the three patients studied with isotopes, blood from two other men with thalassemia, ${ }^{2}$ neither having received blood transfusions within 4 months, was obtained for this portion of the study. Reticulocyte counts and fetal hemoglobin determinations were performed on the separated layers (14) as well as on the whole blood.

\section{RESULTS}

In each of the three patients with thalassemia, the rate of movement of the labeled glycine was more rapid through the circulating pools of hemoglobins $A$ and $A_{2}$ than it was through that of hemoglobin F (Figures 2-6). Although each attained maximal SA at nearly the same time, the peaks for $\mathrm{A}$ and $\mathrm{A}_{2}$ exceeded that for $\mathrm{F}$ by a factor of approximately 1.3. The negative slopes that follow the peaks provide estimates of the survival of the individual hemoglobins. In each case, $A$ and $A_{2}$ have steeper negative slopes than $\mathrm{F}$. These isotopic findings strongly suggest that the turnover of hemoglobins $\mathrm{A}$ and $\mathrm{A}_{2}$ is more rapid than that of $\mathrm{F}$ in these patients. This evidence confirms the findings of Singer and Fisher, who showed a longer survival of hemoglobin $F$ than of $S$ in sickle-cell anemia (15), as well as

\footnotetext{
$2 \mathrm{We}$ acknowledge the kind cooperation of Drs. Jack Braunwald, Alan Sandler, and Mehrian Goulian of the Massachusetts General Hospital for providing these blood samples.
}

those of Buffa, Resegotti, and Maraini, who observed the relative uptake of radioiron into hemoglobins $\mathrm{A}$ and $\mathrm{F}$ in one patient with thalassemia (16). A case reported by Ranney and Kono showed a contrary result, but, as the authors point out, previous transfusion made the interpretation difficult (17).

Previous investigators have described the contour of the curve of appearance and disappearance of labeled glycine through the circulating red cells of normal and abnormal subjects $(18,19)$. The normal curve achieves a maximum at 20 to 30 days, then maintains a plateau until red-cell death from senescence begins. At this point (approximately 100 days), the decline of the curve begins. The maximal decrement of the down slope usually occurs at 120 days, the normal mean life span of the red cell. In contrast, when red-cell death is due to random events, a decline in SA begins soon after the attainment of peak activity. In the analyses that follow, we shall speak of "random" and "senescent" death in this sense.

A description of the $A$ and $F$ curves of patient J.C. was provided in a preliminary report (20). His hemoglobin $F$ curve (Figure 2) describes a normal appearance of senescent death, except that the mean life span is shortened to 104 days, as estimated by the method of Neuberger and Niven (21). In contrast, the gradual negative slopes of the $A$ and $A_{2}$ curves begin immediately after the peaks, indicating a low order of random destruction, with mean life spans of approximately 74 days. The turnover rates in the circulation 
TABLE I

Clinical data pertaining to patients with thalassemia studied with $C^{14}$-glycine

\begin{tabular}{|c|c|c|c|c|c|c|c|c|c|c|c|c|}
\hline \multirow[b]{2}{*}{ Patient } & \multirow[b]{2}{*}{ Age } & \multirow{2}{*}{$\begin{array}{l}\text { Hemo- } \\
\text { globin }\end{array}$} & \multicolumn{3}{|c|}{ Red-cell indexes* } & \multirow{2}{*}{$\begin{array}{l}\text { Nucleated } \\
\text { red cells }\end{array}$} & \multirow{2}{*}{$\begin{array}{l}\text { Serum } \\
\text { bili- } \\
\text { rubin }\end{array}$} & \multirow{2}{*}{$\begin{array}{c}\text { Red- } \\
\text { cell } \\
\text { survival, } \\
\mathrm{Cr}^{61} \mathrm{t}_{\frac{1}{2}}\end{array}$} & \multicolumn{3}{|c|}{$\begin{array}{l}\text { Hemoglobin } \\
\text { composition }\end{array}$} & \multirow{2}{*}{$\begin{array}{c}\text { Sple- } \\
\text { nectomy }\end{array}$} \\
\hline & & & $\mathrm{MCH}$ & $\mathrm{MCHC}$ & $\mathrm{MCV}$ & & & & $\mathrm{A}$ & $\mathrm{A}_{2}$ & $\mathrm{~F}$ & \\
\hline & & $\mathrm{g} / 100 \mathrm{ml}$ & $\mu \mu g$ & $\mathrm{~g} / 100 \mathrm{ml}$ & $\mu^{3}$ & $\begin{array}{c}/ 100 \\
\text { leuko- } \\
\text { cytes }\end{array}$ & $\begin{array}{c}\mathrm{mg} / \\
100 \mathrm{ml}\end{array}$ & days & \multicolumn{3}{|c|}{$\%$ of total } & \\
\hline J.C. & 33 & 9.8 & 21 & 32 & 66 & $<1$ & 2.2 & 24 & 55 & 5 & 40 & No \\
\hline S.D. & 33 & 9.4 & 20 & 29 & 69 & 98 & 2.5 & & 71 & 7 & 22 & Yes \\
\hline C.G. & 43 & 11.5 & 27 & 30 & 91 & 59 & 1.2 & 24 & 5 & 1 & $94 \dagger$ & Yes \\
\hline
\end{tabular}

*Abbreviations used: $\mathrm{MCH}=$ mean corpuscular hemoglobin, $\mathrm{MCHC}=$ mean corpuscular hemoglobin concentration, $\mathrm{MCV}=$ mean cor puscular volume.

t Estimated by difference.

of hemoglobins $A$ and $A_{2}$ are therefore approximately 1.3 times that of $F$, as estimated from their relative mean life spans.

Figure 3 demonstrates the hemoglobin SA curves of patient S.D., which are considerably more complex than those of the other two patients. Within a day or two of the attainment of SA maxima of hemoglobins $A$ and $A_{2}$, there is an abrupt drop in activity that must signify the destruction of very short-lived molecules and presumably of red cells also. A continuously declining slope, indicative of random destruction of the remaining red cells, is then observed. The hemoglobin $\mathrm{F}$ curve also demonstrates a decline in SA immediately after the peak, but the slope of the decline is much less precipitous than that of the other hemoglobins. After this phase, a plateau appears in the $\mathrm{F}$ curve, indicative of a population of F-containing cells that are removed by senescence.

Although these curves are probably too complex to permit accurate mathematical analysis, a clearer picture of the kinetic events may be obtained by applying simple mathematical methods to single-compartment systems. Such a model surely oversimplifies the kinetics, but its use may provide a semiquantitative concept of the hemoglobin turnover rates in this patient. In Figure 4, the points for hemoglobin $A$ and $A_{2}$ are plotted on a semilogarithmic scale beginning with the maximal values. The points fit a two-component exponential system, one component with a half life of about 1 day, containing approximately $30 \%$ of the total circulating pool of $\mathrm{A}$, and the other with a half life of 29 days, containing the remaining $70 \%$. The points for hemoglobin $\mathrm{F}$ are replotted on linear scale from the peak onward in Figure 5. The complicated curve is analyzed as the summation of two curves, one representing a senescent population with a mean life span of 75 days, and the other, whose points well fit an exponential function, representing a population undergoing random destruction with a half life of 9 days. Each population contains $50 \%$ of the total $\mathrm{F}$ pool. From this model, turnover rates for "fast" and "slow" pools for each of the individual hemoglobins may be computed.

TABLE II

Estimation of absolute production rates of rapidly and slowly turning over pools of the individual hemoglobins of patient S.D.*

\begin{tabular}{|c|c|c|c|c|c|c|c|c|}
\hline \multirow{3}{*}{\multicolumn{2}{|c|}{ Hemoglobin }} & \multicolumn{3}{|c|}{ Rapid pools } & \multicolumn{3}{|c|}{ Slow pools } & \multirow{3}{*}{$\begin{array}{l}\text { Total } \\
\text { hemo- } \\
\text { globin } \\
\text { turn- } \\
\text { over }\end{array}$} \\
\hline & & \multirow{2}{*}{$\begin{array}{c}\% \text { of } \\
\text { total } \\
\text { hemo- } \\
\text { globin } \\
\text { pool }\end{array}$} & \multicolumn{2}{|c|}{ Renewal rate } & \multirow{2}{*}{$\begin{array}{c}\% \text { of } \\
\text { total } \\
\text { hemo- } \\
\text { globin } \\
\text { pool }\end{array}$} & \multicolumn{2}{|c|}{ Renewal rate } & \\
\hline & & & Fractional & Absolute & & Fractional & Absolute & \\
\hline \multirow{5}{*}{$\begin{array}{l}\mathrm{A} \\
\mathrm{A}_{2} \\
\mathrm{~F}\end{array}$} & $\%$ of total & & $\% / d a y$ & $g / d a y$ & & $\% / d a y$ & g/day & g/day \\
\hline & 71 & 20 & 69 & 44 & 51 & 2.4 & 3.9 & 48 \\
\hline & 6.9 & 2.0 & 46 & 2.9 & 5.0 & 2.7 & 0.4 & 3.3 \\
\hline & 22 & 11 & 7.7 & 2.8 & 11 & 1.3 & 0.5 & 3.3 \\
\hline & & & & & & \multicolumn{2}{|c|}{ Total g per day } & 55 \\
\hline
\end{tabular}

* Pools of hemoglobin are analyzed in Figures 4 and 5 and are based on a circulating hemoglobin mass of $322 \mathrm{~g}$. 
TABLE III

Patterns of $S A$ of hemoglobins $F$ and $A_{3}$ relative to that of hemoglobin $A$ expressed as ratios

\begin{tabular}{|c|c|c|c|c|c|}
\hline \multirow[b]{2}{*}{$\begin{array}{l}\text { Day of of } \\
\text { study* }\end{array}$} & & \multicolumn{2}{|c|}{ Patient J.C. } & \multicolumn{2}{|c|}{ Patient S.D. } \\
\hline & & $\frac{\mathrm{F}}{\mathrm{A}}$ & $\frac{A_{3}}{A}$ & $\frac{F}{A}$ & $\frac{A_{3}}{A}$ \\
\hline 5 & & .82 & .33 & .60 & .43 \\
\hline 7 & 1 & .81 & .42 & .59 & .48 \\
\hline 23 & & & & .84 & .75 \\
\hline 30 & $a^{2}$ & .81 & .54 & & \\
\hline 51 & $\therefore$ & & & 1.30 & 1.28 \\
\hline $\begin{array}{l}72 \\
76\end{array}$ & $\because$ & 1.16 & .89 & 138 & 128 \\
\hline 100 & $\ldots$ & 1.27 & 1.69 & & \\
\hline
\end{tabular}

* Representative days are selected.

The absolute turnover rates of each of these pools are shown in Table II, which demonstrates several important points. The total hemoglobin production of $55 \mathrm{~g}$ per day represents an expansion of hemoglobin synthesis to approximately 8 times the resting, normal condition and illustrates that this patient not only has an excellent erythroid marrow reserve, but also that the reserve remains in full use. Of the total hemoglobin production, approximately $80 \%$ is expended in the synthesis of a pool of hemoglobin A with a half life of 1 day. Thus the patient evinces a markedly increased turnover of circulating hemoglobin. This process involves hemoglobin A to a disproportionate degree. What significance may be assigned to the previous splenectomy is not apparent, since patient C.G. also underwent splenectomy and showed dissimilar curves. It is important to note that Heinz body inclusions were prominent in the red cells of S.D. and of C.G., in the latter to a lesser degree. These inclusions have been described in splenectomized patients with beta thalassemia by Fessas (22). Their contribution, if any, to the bizarre hemoglobin SA curves awaits further investigation.

Patient C.G. (Figure 6) was particularly interesting because of his extraordinarily high concentration of fetal hemoglobin (94\%). We wondered whether such elevated levels of hemoglobin $\mathrm{F}$ occurred as a result of extraordinarily rapid turnover rates of hemoglobin A. Our study of this patient answered the question in the negative. Although we found the same qualitative pattern as in the other patients, the mean life span of the hemoglobins $A$ and $A_{2}$ was approxi- mately 60 days, as compared to 95 days for fetal hemoglobin; this result compares with that for J.C., who had only $40 \% \mathrm{~F}$.

The proper interpretation of these hemoglobin life-span curves depends, among other things, upon the assumption that the difference found between hemoglobins $A$ and $F$ is not due just to the removal from hemoglobin $A$ of the minor component designated by Kunkel and Bearn as hemoglobin $\mathrm{A}_{3}$ (23). This component has been described by them and by Ranney and Kono (17) as maintaining a lower SA than hemoglobin A early in the course of a red-cell life span, whereas later, as the cells age, the $\mathrm{SA}$ of $\mathrm{A}_{3}$ actually rises above that of the main component. Therefore it has been thought that $A_{3}$, in spite of its altered electrophoretic and chromatographic properties, does not emerge from the ribosomes as such, but rather arises from some modification during ageing of hemoglobin A. The data of Table III confirm this peculiar isotopic pattern of hemoglobin $\mathrm{A}_{3}$. One may calculate, however, that the SA difference between $A_{3}$ and $A$ is not sufficient to account for the difference found between $A$ and $\mathrm{F}$, based on the evidence that $\mathrm{A}_{3}$ constitutes from only 4 to $12 \%$ of the total $\mathrm{A}(10,23)$. It is clear from our chromatographic separations that the proportion of $A_{3}$ is not significantly increased in thalassemia.

If fetal hemoglobin improves the survival of red cells in thalassemia, old red cells should show a higher proportion of fetal hemoglobin than young. Old and young red cells from the three patients discussed above and from two other pa-

TABLE IV

Relative concentrations of fetal hemoglobin in young and old 1 red cells as separated by centrifugation in five men with thalassemia

\begin{tabular}{|c|c|c|c|c|c|c|}
\hline \multirow[b]{2}{*}{ Patient } & \multicolumn{2}{|c|}{ Whole blood } & \multicolumn{2}{|c|}{$\begin{array}{l}\text { Reticulocyte- } \\
\text { rich layer }\end{array}$} & \multicolumn{2}{|c|}{$\begin{array}{l}\text { Reticulocyte- } \\
\text { poor layer }\end{array}$} \\
\hline & $\begin{array}{l}\text { Fetal } \\
\text { hemo- } \\
\text { globin }\end{array}$ & $\begin{array}{l}\text { Retic- } \\
\text { ulo- } \\
\text { cyte } \\
\text { count }\end{array}$ & $\begin{array}{l}\text { Fetal } \\
\text { hemo- } \\
\text { globin }\end{array}$ & $\begin{array}{c}\text { Retic- } \\
\text { ulo- } \\
\text { cyte } \\
\text { count }\end{array}$ & $\begin{array}{l}\text { Fetal } \\
\text { hemo- } \\
\text { globin }\end{array}$ & $\begin{array}{c}\text { Retic- } \\
\text { ulo- } \\
\text { cyte } \\
\text { count }\end{array}$ \\
\hline & $\%$ & $\%$ & $\%$ & $\%$ & $\%$ & $\%$ \\
\hline J.C. & 40 & 0.9 & 14 & 18 & 47 & 0.1 \\
\hline S.D. & 22 & 9.0 & 4 & 53 & 27 & 1.5 \\
\hline C.G. & $84 *$ & 4.0 & 71 & 25 & 86 & 0.2 \\
\hline J.Cr. & 83 & 5.3 & 64 & 18 & 90 & 0.1 \\
\hline P.F. & 30 & 5.4 & 14 & 16 & 35 & 1.1 \\
\hline
\end{tabular}

* This number comes from the alkali denaturation test and differs from that in Table I, which was calculated by difference. 


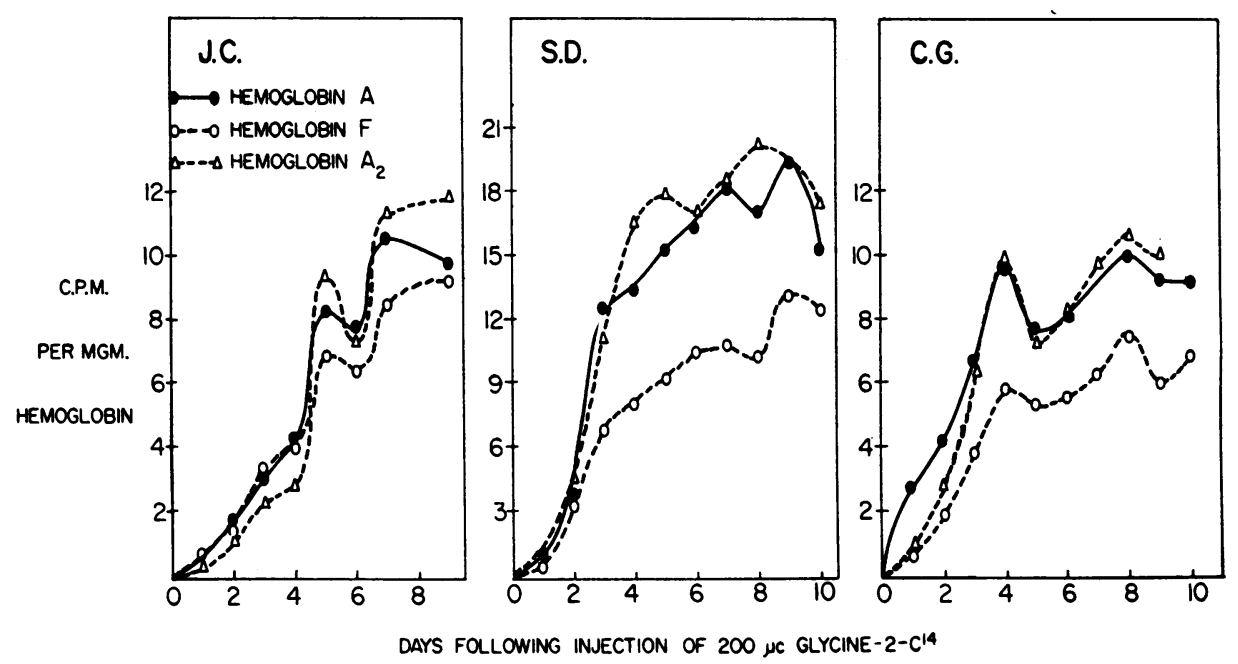

Fig. 7. SA of the individual hemoglobins of three adult patients with thalassemia DURING THE FIRST 10 DAYS AFTER IV INJECTION OF $200 \mu \mathrm{C}$ GLYCINe-2-C ${ }^{14}$. Patient C.G. consumed $2 \mathrm{~g}$ ordinary glycine daily in the form of commercial gelatin during the first 8 days.

tients were separated by centrifugation, and the fetal hemoglobin content of the various layers was determined. The results (Table IV) show clearly and consistently that in thalassemia old cells do, in fact, have a higher fetal hemoglobin concentration than young ones, thereby confirming the isotopic data. Although density, upon which the centrifugal separation depends, is not strictly a function of cellular age, the number of reticulocytes in the top layers seem great enough to dispel doubt that these were layers of young cells.

The staining technique for fetal hemoglobin of Betke and Kleihauer (24) was performed on blood films of the patients and also indicated, as most other investigators have thought (25-27), that the distribution of fetal hemoglobin among the red cells was unequal. The heterogeneous hemoglobin content of the red cells in thalassemia, however, makes the interpretation difficult.

In Figure 7, SA curves for the first 10 days of each study are shown on an enlarged scale. A1though hemoglobins $\mathrm{A}$ and $\mathrm{A}_{2}$ follow similar patterns, consistent differences can be observed. $\mathrm{A}_{2}$ seems to achieve a slightly higher peak SA than A. The significance, if any, of this finding in thalassemia patients is unknown, since similar studies have not yet been performed in normal subjects.

\section{DISCUSSION}

The simultaneous occurrence of hemoglobins $\mathrm{A}, \mathrm{A}_{2}$, and $\mathrm{F}$ in thalassemia presents an opportunity to make significant comparisons of hemoglobin turnover because so many of the variables that may complicate studies based on isotopic techniques may be common to all the hemoglobins. The data of Breathnach indicate that fetal and adult hemoglobin are synthesized side by side in the bone marrow (28), and there seems to be no special predilection for one or the other to be made in extramedullary sites (29). We can therefore safely assume that the cells making these hemoglobins are all bathed in the same extracellular pool of glycine. Beyond this point, we are forced to assume that there are no special differences of membrane transport or of intracellular amino-acid pool sizes among the erythroid series that are not direct reflections of synthetic activity. Available data indicate that there is no difference in glycine content of the three hemoglobins $(30,31)$. Fetal hemoglobin, however, has 12 more serine residues than hemoglobins $A$ and $A_{2}$, and this difference could possibly influence the fetal curves through conversion of glycine to serine in vivo (32).

The results of this investigation clearly indicate that the turnover rate of hemoglobin $F$ is slower than that of hemoglobin $\mathrm{A}$ in thalassemia. 
This difference in metabolism is achieved because of the longer survival in the circulation of those red cells containing relatively greater amounts of fetal hemoglobin. Conversely, red cells containing relatively greater amounts of hemoglobin $\mathrm{A}$ have a shorter survival. Heterogeneous metabolism has been achieved, at least in part, by heterogeneous cellular distribution.

In patients heterozygous for hereditary persistence of fetal hemoglobin, the cellular distribution of fetal hemoglobin appears to be homogeneous (26). That these patients achieve hemoglobin $\mathrm{F}$ concentrations of only 12 to $38 \%$ has been used as an argument for the lower postnatal synthetic rate of hemoglobin $\mathrm{F}$ as compared to hemoglobin A (33). The nature of the life spans of the individual hemoglobins in this condition has not yet been described.

In no conditions other than thalassemia and homozygous persistence of fetal hemoglobin does hemoglobin $\mathrm{F}$ appear in concentrations of over $50 \%$ after infancy (34). One reason for its persistence in thalassemia may be its better survival in the peripheral blood and bone marrow. Thus the persistence of fetal hemoglobin in thalassemia may occur, rather than as a compensatory phenomenon, as the result of natural selection operating on two populations of red cells, the F-rich cells achieving a position of advantage over the A-rich cells through their better survival.

Hemoglobins $A$ and $A_{2}$ may be uniformly distributed among the red cells, since their SA curves are so similar. Such a uniform distribution might result from close linkage of the beta- and deltachain genes on the chromosome, as discussed by Ceppellini (35). Since both hemoglobins A and $\mathrm{A}_{2}$ share the property of more rapid renewal in thalassemia, they may be more responsive to erythropoietic stimuli than hemoglobin $F$. This may be one reason for the selection of the beta chain of hemoglobin $\mathrm{A}$ in preference to the gamma chain of hemoglobin $\mathrm{F}$ in human evolution. It would appear, however, that in beta thalassemia this property of the beta chain may have paradoxically acted to its detriment. since the increased production is associated with more rapid destruction.

Finally, evidence has been presented in one patient that very short-lived red-cell populations may occur in the peripheral blood and involve hemo- globin A predominantly. It is true that the hemoglobin content of the individual red cell is abnormally low in thalassemia. The thalassemic patient may, however, by extensive erythroid proliferation expand his total net hemoglobin production to the same extent as a normal individual maximally stimulated. If hemoglobin $A$ is disproportionately involved in ineffective erythropoiesis, it may be well to substitute the noncommittal term "dyspoiesis" in place of "suppression" to describe the genetic defect of hemoglobin A polypeptide chain synthesis in thalassemia.

\section{SUMMARY}

In a study of three adult thalassemia patients given labeled glycine, the fractional turnover of hemoglobin $\mathrm{A}$ exceeded that of hemoglobin $\mathrm{F}$ in each case. The finding was confirmed in these and in additional patients by comparison of young and old red cells separated by centrifugation. On the other hand, the fractional turnovers of hemoglobins $\mathrm{A}$ and $\mathrm{A}_{2}$ were similar. In one patient, a large fraction of red cells rich in hemoglobin A exhibited a half life of only 1 day. There was no apparent relationship between the turnover rate of hemoglobin A and the concentration in the blood of hemoglobin $\mathrm{F}$.

\section{APPENDIX}

Supplementary genctic data. Patient J.C. is of Italian ancestry. The hemoglobin pattern in the family is as follows: father, $8.6 \% \mathrm{~A}_{2}$ and $1.6 \% \mathrm{~F}$; mother, $5.0 \% \mathrm{~A}_{2}$ and $2.3 \% \mathrm{~F}$. His three children have 9.0, 6.1, and $5.9 \%$ $\mathrm{A}_{3}$, and $4.7,3.2$, and $3.8 \% \mathrm{~F}$, respectively. His wife is Irish and has normal red cells and normal concentrations of $A_{2}$ and $F$.

Patient S.D. is of Italian ancestry. The hemoglobin pattern in the family is as follows: father, $4.7 \% \mathrm{~A}_{2}$ and $1.7 \% \mathrm{~F}$; mother, $4.7 \% \mathrm{~A}_{2}$ and $2.5 \% \mathrm{~F}$. Two children are under the age of two and have not yet been studied. ${ }^{3}$

Patient C.G. is of Greek ancestry. His father is dead. His mother has $8.3 \% \mathrm{~A}_{2}$ and $1.4 \% \mathrm{~F}$. Of thirteen siblings, one died at thirteen with anemia; another is said to have thalassemia, but is not available for study. One sibling has normal red-cell morphology and normal $\mathrm{A}_{2}$ and $\mathrm{F}$ levels. Another has microcytosis without target cells and has $2.2 \% \quad \mathrm{~A}_{2}$ and $2.3 \% \mathrm{~F}$. Eight of the siblings were found to have fetal hemoglobin levels ranging from 14 to $26 \%$, with $\mathrm{A}_{2}$ levels from 1.9 to $3.6 \%$. All of these had abnormal red-cell morphology consistent with thalassemia trait, hemoglobin values of from

${ }^{3}$ Dr. Park Gerald has kindly supplied most of the data regarding J.C. and S.D. 
10.8 to $13.9 \mathrm{~g}$ per $100 \mathrm{ml}$, and mean corpuscular hemoglobin concentrations of from 29 to $33 \mathrm{~g}$ per $100 \mathrm{ml}$. Four members of this group were studied more intensively and were found to have mean corpuscular volumes of from 69 to $77 \mu^{3}$, fasting serum iron of from 75 to 120 $\mu \mathrm{g}$ per $100 \mathrm{ml}$, and slightly increased osmotic resistance. The patient has one grown daughter with $5.0 \% \quad \mathrm{~A}_{2}$ and $5.4 \% \mathrm{~F}$, with morphologic changes of thalassemia trait. Her mother, who is of Polish-Irish ancestry, is not available for study. We consider this family to be one in which thalassemia occurs in association with unusually high levels of fetal hemoglobin.

Insofar as all three patients and their families show elevations of $A_{2}$ or $F$ hemoglobins, or both, they might be described as beta thalassemia intermediaries, probably homozygous.

\section{ACKNOWLEDGMENT}

Dr. Park Gerald participated in the discussion and review of this work and, with Dr. J. Lawrence Naiman, advised us in many of the techniques employed. Dr. Giorgio Segre, of the University of Turin, pointed out to us the limitations of the mathematical analyses applied. Dr. Caesar Tedeschi of the Framingham Union Hospital cooperated in the study of S.D. Above all, we express our appreciation to our patients, J.C., S.D., and C.G.

\section{REFERENCES}

1. Itano, H. A. The human hemoglobins: their properties and genetic control. Advanc. Protein Chem. $1957,12,215$.

2. Ingram, V. M., and A. O. W. Stretton. Genetic basis of the thalassaemia diseases. Nature (Lond.) 1959, 184, 1903.

3. Rucknagel, D. L., and J. V. Neel. The hemoglobinopathies in Progress in Medical Genetics, A. G. Steinberg, Ed. New York, Grune \& Stratton, 1961, vol. 1, p. 158.

4. Giblett, E. R., D. H. Coleman, G. Pirzio-Biroli, D. M. Donohue, A. G. Motulsky, and C. A. Finch. Erythrokinetics: quantitative measurements of red cell production and destruction in normal subjects and patients with anemia. Blood 1956, 11, 291.

5. Sturgeon, P., and C. A. Finch. Erythrokinetics in Cooley's anemia. Blood 1957, 12, 64.

6. Bailey, I. S., and T. A. J. Prankerd. Studies in thalassaemia. Brit. J. Haemat. 1958, 4, 150.

7. Malamos, B., E. H. Belcher, E. Gyftaki, and D. Binopoulos. Simultaneous radioactive tracer studies of erythropoiesis and red cell destruction in thalassaemia. Brit. J. Haemat. 1961, 7, 411.

8. Grinstein, M., R. M. Bannerman, J. D. Vavra, and C. V. Moore. Hemoglobin metabolism in thalassemia. In vivo studies. Amer. J. Med. 1960, 29, 18.

9. Robinson, S., T. Vanier, J. F. Desforges, and R. Schmid. Jaundice in thalassemia minor: a con- sequence of "ineffective erythropoiesis". New Engl. J. Med. 1962, 267, 523.

10. Allen, D. W., W. A. Schroeder, and J. J. Balog. Observations on the chromatographic heterogeneity of normal adult and fetal human hemoglobin: a study of the effects of crystallization and chromatography on the heterogeneity and isoleucine content. J. Amer. chem. Soc. 1958, 80, 1628.

11. Huisman, T. H. J., E. A. Martis, and A. Dozy. Chromatography of hemoglobin types on carboxymethylcellulose. J. Lab. clin. Med. 1958, 52, 312.

12. Schoeniger, W. Eine mikro analytische Schnellbestimmung von Halogen in organische Substancen. Mikrochim. Acta 1955, 123.

13. Nathan, D. G., T. G. Gabuzda, and F. H. Gardner. J. Lab. clin. Med. In press.

14. Chernoff, A. I. The human hemoglobins in health and disease. New Engl. J. Med. 1955, 253, 322.

15. Singer, K., and B. Fisher. Studies on abnormal hemoglobins. V. The distribution of type S (sickle cell) hemoglobin and type $\mathrm{F}$ (alkali resistant) hemoglobin within the red cell population in sickle cell anemia. Blood 1952, 7, 1216.

16. Buffa, F., L. Resegotti, and G. Maraini. Ricerche sull'utilizzazione di ferro radioattivo nelle emoglobine adulta e fetale in un sogetto adulto con morbo di Cooley. Haematolog:ca 1958, 43, 1237.

17. Ranney, H. M., and P. Kono. Studies on the incorporation of $\mathrm{Fe}^{5 \theta}$ into normal and abnormal hemoglobins. J. clin. Invest. 1959, 38, 508.

18. London, I. M., D. Shemin, R. West, and D. Rittenberg. Heme synthesis and red blood cell dynamics in normal humans and in subjects with polycythemia vera, sickle cell anemia, and pernicious anemia. J. biol. Chem. 1949, 179, 463.

19. Berlin, N. I., J. H. Lawrence, and H. C. Lee. The pathogenesis of the anemia of chronic leukemia: measurement of the life span of the red blood cell with glycine-2-C ${ }^{14}$. J. Lab. clin. Med. 1954, 44, 860 .

20. Gabuzda, T. G., D. G. Nathan, and F. H. Gardner. Comparative metabolism of hæmoglobins $\mathrm{A}$ and $\mathrm{F}$ in thalassaemia. Nature (Lond.) 1962, 196, 781.

21. Neuberger, A., and J. S. F. Niven. Haemoglobin formation in rabbits. J. Physiol. (Lond.) 1951, 112, 292.

22. Fessas, $P$. Inclusions of hemoglobin in erythroblasts and erythrocytes of thalassemia. Blood 1963, 21, 21.

23. Kunkel, H. G., and A. G. Bearn. Minor hemoglobin components of normal human blood. Fed. Proc. 1957, 16, 760.

24. Betke, K., and E. Kleihauer. Fetaler und bleibender Blutfarbstoff in Erythrozyten und Erythroblasten von menschlichen Feten und Neugeborenen. Blut 1958, 4, 241.

25. Shepard, M. K., D. J. Weatherall, and C. L. Conley. Semiquantitative estimation of the distribution of fetal hemoglobin in red cell populations. Bull. Johns Hopk. Hosp. 1962, 110, 293. 
26. Thompson, R. B., J. W. Mitchener, and T. H. J. Huisman. Studies on the fetal hemoglobin in the persistent high $\mathrm{Hb}-\mathrm{F}$ anomaly. Blood 1961, 18, 267.

27. Raper, A. B., and I. D. Freser. Fœtal hæmoglobin synthesis in some hæmoglobinopathies. Lancet 1961, 1, 1224.

28. Breathnach, C. S. Some observations on the erythrocyte pigment relationships in neonatal blood and marrow. Quart. J. exp. Physiol. 1962, 47, 141.

29. Thomas, E. D., H. C. Lochte, W. B. Greenough, and $\mathrm{M}$. Wales. In vitro synthesis of fœetal and adult hæmoglobin by fœtal hæmatopoietic tissues. $\mathrm{Na}$ ture (Lond.) 1960, 185, 396.

30. Schroeder, W. A., J. R. Shelton, J. B. Shelton, and $\mathrm{J}$. Cormick. Further sequences in the $\boldsymbol{\gamma}$ chain of human fetal hemoglobin. Proc. nat. Acad. Sci. (Wash.) 1962, 48, 284.

31. Baglioni, C. The fusion of two peptide chains in hemoglobin Lepore and its interpretation as a genetic deletion. Proc. nat. Acad. Sci. (Wash.) 1962, 48, 1880.

32. Borsook, H., C. L. Deasy, A. J. Haagen-Smit, G. Keighley, and P. H. Lowy. Incorporation in vitro of labeled amino acids into proteins of rabbit reticulocytes. J. biol. Chem. 1952, 196, 669.

33. Conley, C. L., D. L. Weatherall, S. N. Richardson, M. K. Shepard, and S. Carache. Hereditary persistence of fetal hemoglobin: a study of 79 affected persons in 15 Negro families in Baltimore. Blood 1963, 21, 261.

34. Wheeler, J. T., and J. R. Krevans. The homozygous state of persistent fetal hemoglobin and the interaction of persistent fetal hemoglobin with thalassemia. Bull. Johns Hopk. Hosp. 1961, 109, 217.

35. Ceppellini, R. in The genetical control of protein structure: the abnormal human hæmoglobins by J. A. Hunt and V. M. Ingram in Biochemistry of Human Genetics, G. E. W. Wolstenholme and C. M. O'Connor, Eds. London, Churchill, 1959, p. 133. 